\title{
IMPLEMENTASI PEMBELAJARAN BAHASA INGGRIS ANAK MELALUI METODE GERAK DAN LAGU UNTUK ANAK PAUD
}

\author{
Yuspar Uzer, M.Pd \\ Univ. PGRI Palembang \\ Email: yusparu@gmail.com
}

\begin{abstract}
Abstrak : Kesadaran akan pentingnya penguasaan bahasa Inggris di era informasi ini memunculkan upayaupaya untuk mempelajari dan menguasai bahasa tersebut sedini mungkin melalui metode gerak dan lagu. Oleh karena itu, bahasa Inggris diharapkan untuk diperkenalkan di lembaga pendidikan formal untuk anak usia dini. Hal ini menjadi sebuah tantangan tersendiri karenabahasa Inggris merupakan bahasa asing di Indonesia. Ketika sebuah bahasa asing diperkenalkan kepada anak usia dini, maka pengetahuan khusus mengenai bagaimana anak memperoleh dan mempelajari bahasa sangat diperlukan, sehingga sebuah metode pembelajaran yang tepat dapat dirumuskan dengan baik. Artikel ini membahas mengenai proses pemerolehan bahasa pada anak, baik pada bahasa pertamanya maupun bahasa keduanya, serta bagaimana pengetahuan mengenai proses tersebut berperan dalam perumusan metode pembelajaran bahasa Inggris melalui metode gerak dan lagu untuk anak usia dini.
\end{abstract}

Kata Kunci: Pembelajaran Bahasa Inggris, Metode melalui metode gerak dan lagu, dan Anak Usia Dini

\section{PENDAHULUAN}

Pembelajaran adalah proses interaksi antar anak didik antara anak didik dan pendidik dengan melibatkan orang tua serta sumber belajar pada suasanabelajar dan bermain di satuan atau program PAUD (Permendikbud, Pasal 1:13).

Kegiatan pembelajaran pada anak usia dini pada hakikatnya adalah pengembangan kurikulum secara konkret berupa seperangkat rencana yang berisi sejumlah pengalaman belajar melalui bermain yang diberikan kepada anak usia dini berdasarkan potensi dan tugas perkembangan yang harus dikuasainya dalam rangka pencapaian kompetensi yang harus dimiliki oleh anak (Sujiono dan Sujiono, 2007:26 dalam Mursid 2015). Mengingat pembelajaran bahasa Inggris diberikan kepada anak sejak dini, maka dalam pembelajarannya perlu disesuaikan dengan tingkat perkembangan anak. Menurut Standar Tingkat Pencapaian Perkembangan Anak Pasal 7, Perkembangan anak sebagaimana dimaksud ayat (1) merupakan integrasi dari perkembangan aspek nilai agama dan moral, fisikmotorik, kognitif, bahasa, dan sosial emosional, serta seni. Tentunya semua itu tidak terlepas dari kurikulum TK yang dibuat khususnya pada program pembelajaran bahasa Inggris, hendaknya di desain secara sederhana, menarik dan tetap memperhatikan prinsip belajar anak. Selain itu, agar materi pembelajaran bahasa Inggris yang diajarkan kepada anak dapat mudah diserap serta dikuasai oleh 
anak secara optimal, maka guru pun harus memiliki kemampuan mengajar dengan tepat serta mampu menciptakan lingkungan belajar kondusif. Dengan begitu suasana belajar anak akan senantiasa menggembirakan dan lebih bermakna tentunya.

Metode yang paling sering digunakan dalam pembelajaran bahasa Inggris di TK tersebut adalah metode gerak dan lagu. Melalui lagu (music) anak dapat menemukan cara belajar yang mengasyikkan. Saat anak diperkenalkan lagu dengan memiliki lirik bahasa asing (bahasa Inggris), secara tidak langsung anak akan mengenal kata-kata asing (bahasa Inggris). Biasanya lagu-lagu kanak-kanak dapat dinyanyikan sambil bermain atau beraktivitas lainnya. Karena dianggap sebagai permainan, maka anak akan termotivasi untuk mendengarkan, mempelajari, dan mengucapkannya (Rachmi, 2008). Dengan demikian pemanfaatan lagu anak-anak akan sangat ideal digunakan untuk mengajarkan bahasa Inggris kepada anak usia dini, yang selanjutnya dapat membantu mengoptimalkan kemampuan berbahasa Inggris anak. Sementara gerakan (movement) merupakan bahasa tubuh. Anak mengekspresikan perasaannya melalui aktivitas gerakan setelah mendengarkan nyanyian. Anak memiliki hubungan yang aktif dalam merespon nyanyian. Melalui gerak dan tubuhnya akan dapat digambarkan apa yang dirasakan dan dimengerti oleh anak tersebut terhadap musik (nyanyian). Aktivitas gerakan itu sendiri sangat dibutuhkan bagi anak usia dini dalam melatih dan mengembangkan motorik kasar mereka (Matodang 2005).

Tujuan umum pembahasan pada artikel ini adalah untuk memberikan informasi tentang seperti apa pembelajaran bahasa Inggris pada anak usia dini berbasis proses pemerolehan bahasa pertama melalui metode gerak dan lagu. Informasi ini diharapkan dapat bermanfaat untuk kemudian dikaji secara empiris dalam penelitian-penelitian sehingga hasilnya dapat berimplikasi pada percepatan pembangunan anak-anak Indonesia yang memiliki kecakapan berbahasa Inggris. Adapun tujuan khusus dari pembahasan artikel ini adalah untuk mendeskripsikan secara komprehensif tentang (1) proses anak dalam memperoleh bahasa dan dalam pembelajaran bahasa melalui metode gerak dan lagu; dan (2) langkah-langkah implementasi Pembelajaran bahasa Inggris anak Melalui Metode Gerak dan Lagu pada Kelompok B di TK Smile Kids Gandus Palembang Tahun Ajaran 2018/2019 pada anak usia dini berbasis 
proses pemerolehan bahasa pertama melalui metode gerak dan lagu.

\section{METODE PENELITIAN}

Jenis Artikel ini yaitu kualitatif dengan desain penelitian deskriptif. Penelitian deskriptif diartikan sebagai suatu penelitian yang berusaha mendeskripsikan suatu fenomena atau peristiwa secara sistematis sesuai dengan apa adanya (Nyoman, 2013). Tempat yang digunakan sebagai objek penelitian bertempat di TK Smile Kids Gandus, Palembang 2018/2019.

\section{PEMBELAJARAN BAHASA INGGRIS MELALUI GERAK DAN}

LAGU

Istilah pemerolehan bahasa biasanya dibedakan dengan istilah pembelajaranbahasa. Istilah pembelajaran bahasa digunakan berkaitan dengan proses yang terjadi pada waktu seorang anak mempelajari bahasa kedua setelah dia memperoleh bahasa pertamanya. Dengan kata lain, pemerolehan bahasa berkenaan dengan bahasa pertama, sedangkan pembelajaran bahasa berkenaan dengan bahasa kedua (Chaer, 2003, p.167).

Walaupun istilah yang digunakan adalah pemerolehan bahasa kedua, namun istilah itu meliputi segala proses pembelajaran bahasa apapun setelah bahasa pertama, baik itu bahasa kedua, ketiga, keempat dan seterusnya. Oleh karena itu, bahasa lain selain bahasa pertama disebut bahasa kedua atau juga disebut sebagai bahasa target untuk membedakan antara bahasa kedua dan bahasa asing, The Collins Dictionary(2013) mendefinisikan bahasa kedua sebagai bahasa yang dipelajari setelah bahasa ibu nya dan bahasa asing sebagai bahasa yang digunakan di negara selain negara asalnya. Perbedaan utama dari pemerolehan

bahasa pertama dan kedua atau asing adalah pada setting proses belajarnya. Pemerolehan bahasa pertama dilakukan secara alami dan tidak sadar, sedangkan pemerolehan bahasa kedua dilakukan secara sadar dan formal. Oleh sebab itu, proses yang terjadi dalam "kepala" anak pun diduga akan berbeda.Berdasarkan hasil penelitian di atas, diketahui bahwa implementasi Pembelajaran bahasa Inggris anak Melalui Metode Gerak dan Lagu pada Kelompok B di TK Smile Kids Gandus Palembang Tahun Ajaran $2018 / 2019$

Metode Pengajaran di Playgroup \& Kindergarten Point Bilingual School adalah berbasis bilingual, yaitu bahasa Indonesia dan bahasa Inggris Pembelajaran berbasis bilingual diberikan secara optimal kepada anak dalam setiap program 
pembelajaran Menggunakan variasi metode pembelajaran yang terdiri dari 1) Metode Pengajaran dengan konsep Bilingual/dua bahasa (Bahasa Inggris \& Indonesia), 2) Metode Pengajaran Student Oriented, 3) Metode Pengajaran Learning by Playing, 4) Metode Pengajaran Life Skills, dan 5) Metode Pengajaran Fun \& Easy Proses pembelajaran dilakukan secara umum namun pemberian materi bahasa inggris diberikan secara khusus dan banyak menggunakan gerak serta lagu.

Guru di Playgroup \& Kindergarten Point Bilingual School memiliki kesabaran yang tinggi, ceria, kreatif, dan pandai mendekati anak Pelaksanaan pembelajaran terdiri dari kegiatan Funtime (07.30-08.00), 2) Religion (08.00-08.30), 3) Pembelajaran ke-1 yaitu, usap abu (08.30-09.30), 4) Snack time (09.30-09.45), 5) Pembelajaran ke-2 menggunakan majalah (10.00-11.00), 6) Meal (11.00-11.30), 7) Penutup sebelum pulang (11.30-12.00) Menggunakan lagu berbahasa Inggris, diantaranya adalah "If You're Happy and You Know it", "Hello-Hello", dan "One Little Finger".

Berdasarkan pernyataan di atas, dapat ditarik kesimpulan bahwa keberhasilan Playgroup \& Kindergarten Point Bilingual School, dalam meningkatkan keterampilan berbahasa Inggris anak adalah menggunakan metode gerak dan lagu. Dalam gerak dan lagu, kemampuan bahasa Inggris anak dapat meningkat dengan baik, kemudian setiap anak dapat bertambah kosakatanya dengan optimal dan anak mampu menguasai berbagai lagu yang diajarkan oleh guru serta mampu berkomunikasi menggunakan bahasa inggris baik kepada teman maupun guru. .

Temuan penelitian di atas memperkuat hasil penelitian yang pernah dilakukan oleh Fitrianti dan Reza (2013), Sophya (2013), Hijriyah, dkk (2013), bahwa Anak usia 5-6 tahun memiliki potensi yang besar dalam mengembangkan aspek-aspek perkembangannya. Anak mulai sensitif menerima segala rangsangan dari luar. Salah satu aspek perkembangan besar perkembangan fungsi otak berjalan beriringan dengan keterampilan motorik pada usia dini. Oleh sebab itu,motorik menjadi perkembangan yang penting untuk dilatih dan dikembangan pada anak usia dini. Anak usia 5-6 tahun lebih banyak melakuakan aktivitas gerak yang melibatkan motorik kasarnya seperti berlari, melompat, menendang. Oleh sebab itu kegiatan pembelajaran hendaknya dirancang sesuai dengan kebutuhan dan perkembangan anak. Akan tetapi, banyak kegiatan pembelajaran di Taman Kanakkanak yang mengesampingkan aktivitas yang bersifat mengembangkan 
motorik khususnya motorik kasar anak Sebagian besar kegiatan yang dirancang oleh guru yakni untuk pengembangan kognitif, bahasa, sains dan motorik halus. Hal ini dikarenakan adanya tuntutan khususnya dari orang tua bahwa setelah lulus dari taman kanakkanak, anak harus sudah pandai membaca dan menulis. Sesuai dengan perkembangan anak, anak pada usia 5-6 tahun merupakan anak yang aktif. Mereka sangat suka bergerak. Aktivitas atau kondisi bergerak pada anak TK sangat dominan, berdasarkan hasil pengamatan $70 \%$ - $80 \%$ anak TK melakukan gerak pada proses belajarnya. Gerak merupakan sebuah unsur utama dalam pengembangan motorik anak. Banyak manfaat yang dapat diperoleh anak ketika ia mulai terampil dalam menguasai gerakan yakni badan akan semakin sehat, lebih mandiri, percaya diri, serta sosial emosionalnya juga akan berkembang dengan baik.

Melalui gerak anak mampu mengekspresikan dirinya. Untuk mengembangkan serta meningkatkan kemampuan motorik kasar diperlukan adanya kondisi dan stimulasi. Pendidik atau guru harus merancang sebuah kegiatan pembelajaran motorik yang menyenangkan dan sesuai dengan kebutuhan anak. Salah satu bentuk kegiatan yang dapat digunakan yakni melalui lagu atau nyanyian. Nyanyian memiliki banyak manfaat tidak hanya untuk menyenangkan hati anak melainkan dapat digunakan sebagai sarana penyampaian informasi yang menyenangkan untuk anak. Lagu atau nyanyian dapat dirancang sedemikian hingga sesuai dengan tujuan pembelajaran atau tujuan materi yang ingin disampaikan. Menurut Sophya (2013), media pembelajaran dalam proses pembeajaran digunaknan untuk menyampaikan pesan dan materi agar dapat mencapai tujuan pembelajaran. Pada awal penelitian disebutkan bahwa Playgroup \& Kindergarten Point Bilingual School mencantumkan tujuan pembelajaran yaitu turut mencerdaskan kehidupan bangsa sesuai dengan pembukaan UndangUndang Dasar 1945 dan menyediakan tempat, sarana, dan prasarana untuk menambah, mengembangkan, dan meningkatkan ketrampilan generasi penerus kita. Melalui media gerak dan lagu, guru berhasil mengimplementasikan implementasi.

\section{PENUTUP}

Mengajarkan bahasa Inggris pada anak usia dini merupakan sebuah langkah yang tepat (lihat Stakanova dan Tolsikhina, 2014). Namun, anak-anak perlu dilihat sebagai individu yang berbeda 
dengan orang dewasa. Anak-anak dan orang dewasa mempelajari bahasa dengan cara yang berbeda (lihat O'Grady, 2007; Valipour dan Davatgari, 2014); dan bahkan dengan cara yang lebih cepat (lihat Santrock,2007:313). Maka dari itu pembelajaran bahasa Inggris untuk anakanak usia dini memerlukan perlakuan yang berbeda dibandingkan untuk orang dewasa.

Seorang pengajar bahasa Inggris untuk anak usia dini perlu memahami bahwa seorang anak sejak lahir telah memiliki sejumlah kapasitas atau potensi bahasa yang akan berkembang sesuai dengan proses kematangan intelektualnya (lihat Brown, 1980). Seorang anak memiliki apa yang disebut dengan LAD (Language Acquisition Device)yang tidak dimiliki oleh orang dewasayang menjadi bekal bagi dirinya untuk memperoleh dan mengolah bahasa. Dengan LAD anak-anak akan mengembangkan aturan dan memahami bahasa dengan caranya (lihat Well, 1999). Oleh karena itu, tidak perlu untuk mengkotak-kotakan, mendikte apa yang seharusnya dipelajari oleh anak. Pembelajaran bahasa Inggris pada anak usia dini tidak boleh menghambat kreativitas dan imajinasi bahasa anak.

Karakteristik utama dalam implementasi Pembelajaran bahasa Inggris anak Melalui Metode Gerak dan Lagu pada Kelompok B di TK Smile Kids Gandus Palembang Tahun Ajaran 2018/2019 pada anak adalah mendengarkan, mengimitasi, dan mengalami. Maka dari itu diperlukan suatu metode yang tepat untuk mengakomodir karakteristik tersebut. Metode pengajaran langsung (Direct Method) dipercaya masih relevan dan tepat untuk diterapkan dalam pengajaran bahasa Inggris untuk anak usia dini. Yakni metode mengajar secara langsung (tanpa penerjemahan) dan secara konseptual (tanpa kaidah dan penjelasan gramatikal). Pada implementasi Pembelajaran bahasa Inggris anak Melalui Metode Gerak dan Lagu pada Kelompok B di TK Smile Kids Gandus Palembang Tahun Ajaran 2018/2019 tataran teknisnya, guru harus memperbanyak interaksi lisan aktif, penggunaan spontan bahasa, tanpa penerjemahan antara bahasa pertama dan kedua, dan sedikit sekali atau sama sekali tanpa analisis kaidah gramatikal.

\section{DAFTAR PUSTAKA}

Brown, H. D. (2007). Prinsip Pembelajaran dan Pengajaran Bahasa. (Cholis, N. dan Pareanom, Y.A., Trans.) Jakarta, JKT: Kedutaan Besar Amerika Serikat.

Chaer, A. (2003). Psikolinguistik:Kajian Teoretik. Jakarta, JKT: Rineka Cipta Fromkin, 
Fitrianti Diah., \& Muhammad Reza.

(2013). Mengembangkan Kegiatan

Gertak dan Lagu untuk

Meningkatkan Motorik Kasar pada

Anak. Dalam jurnal

mahasiswa.unesa.ac.id/article/6348/

19/article.pdf.

Godstein, E. B. (2008). Cognitive Psychology: Connecting Mind, Research and Everyday Experience. Second Edition. United States of America, USA: Thomson Wadsworth.

Ingram, D. (1989). First Language Acquisition: Method, Description, and Explanation.Great Britain: Cambridge University Press.

Linse, C.T. (2005). Practical English Language Teaching: Young Learners. New York, NY: McGraw-Hill Company Inc.

Lust, B.C. (2006). Child Language: Acquisition and Growth.United Kingdom, UK: Cambridge University Press.

Matodang, Elisabeth Marsaulina. 2005. Menumbuhkan Minat Belajar Bahasa Inggris Anak Usia Dini Melalui Music and Movement (Gerak dan Lagu). Jurnal Pendidikan Penabur - No.05/ Th.IV/ Desember 2005.
O'grady, W. (2005). How Children Learn Language.United Kingdom, UK: Cambridge University Press.

Rodman, R., \& Hyams, N.(1990). An Intoduction to Language. New York, NY: Avon

Books.

Santrock, J. (2007). Adolesence"Fifth Edition. New York, NY: McGrawHill Company Inc.

Schutz, R. (2006). Stephen Krashni's Theory of Second language Acquisition. Diakses dari:

http://www.sk.com.br/skkrash. html.

Sigel, I., \& Cocking, R. (2000). Cognitive Development from Childhood to Adolescence: A Constructivist Perspective' p. 5. Diakses dari: http://fccl.ksu.ru/papers/gp002.htm

Stakanova E., \& Tolstikhina, E. (2014). Different Approaches to Teaching English As A Foreign Language to Young Learner.Procedia Social and Behaviour Science Vo. 146. pp. 456-460. Diakses dari: www.sciencedirect.com

Valipour, V., \& Davatgari, H. (2014). Differences between Children and Adults in Foreign Languange Pronunciation and Gramatical Rules Learning.Indian Journal of Fundamental and Applied Life Sciences Vol. 4 (S3), pp. 195-198. Diakses dari: www.cibtech.org/sp.ed/jls/2014/03/ jls.htm. 